\author{
G.A. Yessenbayeva ${ }^{1}$, D.N. Yesbayeva ${ }^{2}$, N.K. Syzdykova ${ }^{1}$ \\ ${ }^{1}$ Ye.A. Buketov Karaganda State University, Kazakhstan; \\ ${ }^{2}$ Shanghai Factory-Amigo EC Technology Co., Ltd, China \\ (E-mail: esenbaevagulsima@mail.ru)
}

\title{
On the finite element method for calculation of rectangular plates
}

\begin{abstract}
The article is devoted to the study of bending problems for rectangular plates, which are of great applied importance and are found everywhere in various branches of science and technology. The calculation of plate bending is performed by the finite element method. In this article the structure of the method for calculating the deformed and stress state of a rectangular finite element of the plate is described, their main components are highlighted; the classical approach of calculating rectangular plates is characterized. The mathematical apparatus of the calculation is presented in the volume necessary for calculating the plates. This article is focused mainly on mechanics, physicists, engineers and technical specialists.
\end{abstract}

Keywords: finite element method, bending of a rectangular plate, finite element of a plate, plate deflection function, coordinate functions.

Plates are rightly considered the most universal and widespread elements in virtually all sectors of the economy. They are widely used in industry, in construction, in various branches of technology as structural elements and parts of multifarious devices, numerous mechanisms and machines for diverse purposes.

Among the plates of different shapes, a special place is occupied by a rectangular plate, since the rectangular plate has a universal shape and is the basis for the calculation of many plate structures $[1,2]$.

Separate rectangular plates are used in construction in the form of wall panels, wall beams, slabs and floor panels and coatings, foundation slabs, etc. Connected horizontal and vertical plates form the load-bearing system, which in relation to the buildings referred to as the wall system. An obliquely positioned plate can form the span load-bearing structures. The system of rectangular inclined plates, the middle surface of which is deployed on a plane, is called a fold. Folds are also widely used in construction and engineering.

During operation, the plates and plate structures are exposed to temperature, power, mechanical stress, wear, etc. All this causes, first of all, the bending of the plate. Therefore, the theory of plate bending is an important section of the general theory of plates.

To create new plates with specified performance characteristics and strength, it is necessary to investigate how temperature-time, mechanical (including oscillatory), chemical and other influences can cause destructive processes in the structure of the material. Therefore, the required qualities of the plates are usually provided by calculating the effect of such forces on the strength and on the characteristics of the material necessary for operation [3-6].

When calculating the plate strength for bending, it is necessary to have information about its stress-strain state. Many various analytical and approximate methods of plate theory are used for this purpose [7-10]. An exact solution in analytical form for such problems of plate bending is possible only in some particular cases of the geometrical type of the plate, the load and the conditions for its fixation on the supports; therefore, for engineering practice, approximate, but sufficiently accurate methods for solving the considered problem are of special importance.

It should be noted that when calculating the plates by analytical methods in the most general formulation: with arbitrary boundary conditions (including elastic), different types of load, complex shapes of plates, with cuts, projections, etc., we have to face with great mathematical difficulties, and in most cases to obtain an analytical solution is not possible. Such a problem can be solved by applying the very efficient finite element method, which is a numerical approximate method for plates, but which gives a sufficiently high accuracy of solutions.

The finite element method [11] is one of the numerical methods for solving the problems of solid deformable body mechanics. This method is effectively developed in recent years. The name of this method to some extent predetermines its essence: when using the finite element method, the calculated structure is mentally divided 
into separate elements, the stress-strain state of which is previously studied in detail and can be considered known. The finite element method is based on two main ideas: discretization of the object under study on a finite set of elements and piecewise-element approximation of the functions under study.

It is assumed that the elements are connected to each other in a finite number of points, called nodes. At these points, efforts are determined. These efforts characterize the interaction of individual elements, through which, ultimately, stresses and displacements of each element are calculated. Thus, the problem is discretized and reduced to solving a system of algebraic equations with respect to unknown forces or displacements of nodes.

Depending on which quantities are accepted as unknown, there are three classical approaches used in the finite element method: the force method, the displacement method, and the mixed method. Note that due to a number of advantages, the approach based on the idea of the displacement method is the most widespread in the finite element method.

The type of the finite element is determined depending on the type of the structure under consideration. So for rod systems, rods with different fastenings at the ends, which are element nodes, can be taken as the finite element. Thin-walled spatial systems consisting of plates and shells are divided into triangular, rectangular elements or elements of any other shape with nodes at angular points. Next, we consider a rectangular finite element of the plate.

The deformed state of the rectangular finite element of the plate is completely determined by the following parameters [12]

$$
\begin{gathered}
W(x, y)=\vec{q}^{T} \vec{V}, \\
\alpha(x, y)=\left(\vec{q}^{1}\right)^{T} \vec{V}, \quad \beta(x, y)=\left(\vec{q}^{2}\right)^{T} \vec{V}, \\
\xi_{1}(x, y)=\left(\vec{q}^{11}\right)^{T} \vec{V}, \quad \xi_{2}(x, y)=\left(\vec{q}^{22}\right)^{T} \vec{V}, \quad \xi_{12}(x, y)=\left(\vec{q}^{12}\right)^{T} \vec{V}, \\
\vec{q}^{1}=\frac{\partial \vec{q}}{\partial x}, \quad \vec{q}^{2}=\frac{\partial \vec{q}}{\partial y}, \quad \vec{q}^{11}=\frac{\partial^{2} \vec{q}}{\partial x^{2}}, \quad \vec{q}^{12}=\frac{\partial^{2} \vec{q}}{\partial x \partial y}, \quad \vec{q}^{22}=\frac{\partial^{2} \vec{q}}{\partial y^{2}},
\end{gathered}
$$

where $W(x, y)$ is the deflection function; $\alpha(x, y)$ is an angle of rotation (tilt) along the axis $x ; \beta(x, y)$ is an angle of rotation (tilt) along the axis $y ; \xi_{1}(x, y)$ is a curvature of the curve along the axis $x ; \xi_{2}(x, y)$ is a curvature of the curve along the axis $y ; \xi_{12}(x, y)$ is torsion of the curve; $\vec{q}$ is the vector of plate coordinate functions; $\vec{V}$ is the vector of nodal displacements for the finite element of the plate.

Taking into account the formulas of forces and (1)

$$
\begin{gathered}
M_{1}=-D\left(\frac{\partial^{2} W}{\partial x_{1}^{2}}+\nu \frac{\partial^{2} W}{\partial x_{2}^{2}}\right), \quad M_{2}=-D\left(\frac{\partial^{2} W}{\partial x_{2}^{2}}+\nu \frac{\partial^{2} W}{\partial x_{1}^{2}}\right), \quad M_{12}=-D(1-\nu) \frac{\partial^{2} W}{\partial x_{1} \partial x_{2}}, \\
Q_{1}=-D \frac{\partial}{\partial x_{1}}\left(\nabla^{2} W\right), \quad Q_{2}=-D \frac{\partial}{\partial x_{2}}\left(\nabla^{2} W\right), \quad \nabla^{2} W=\frac{\partial^{2} W}{\partial x_{1}^{2}}+\frac{\partial^{2} W}{\partial x_{2}^{2}},
\end{gathered}
$$

where $x=\frac{x_{1}}{a}, y=\frac{x_{2}}{b}, x, y$ are dimensionless coordinates; the stress state of the finite element of the plate is determined as

$$
\begin{gathered}
M_{1}=-D\left(\xi_{1}+\nu \xi_{2}\right)=-D A_{1}^{T} \vec{V}, \quad A_{1}=\vec{q}^{11}+\nu \vec{q}^{22}, \\
M_{2}=-D\left(\xi_{2}+\nu \xi_{1}\right)=-D A_{2}^{T} \vec{V}, \quad A_{2}=\vec{q}^{22}+\nu \vec{q}^{11}, \\
M_{12}=-D(1-\nu) \xi_{12}=-D B^{T} \vec{V}, \quad B=\vec{q}^{12}, \\
Q_{1}=-D C_{1}^{T} \vec{V}, \quad C_{1}=\vec{q}^{111}+\vec{q}^{122}, \\
Q_{2}=-D C_{2}^{T} \vec{V}, \quad C_{2}=\vec{q}^{211}+\vec{q}^{222} .
\end{gathered}
$$

On the basis of (1) and (2) it is easy to determine the deformation and force characteristics for the finite element of the plate at any point with a known vector of nodal displacements $\vec{V}$.

Considering values of functions [13]

$$
\begin{gathered}
f_{1}(x)=2 x^{3}-3 x^{2}+1, \quad f_{2}(x)=x^{3}-2 x^{2}+x, \\
f_{3}(x)=3 x^{2}-2 x^{3}, \quad f_{4}(x)=x^{3}-x^{2} \\
\varphi_{1}(y)=2 y^{3}-3 y^{2}+1, \quad \varphi_{2}(y)=y^{3}-2 y^{2}+y, \\
\varphi_{3}(y)=3 y^{2}-2 y^{3}, \quad \varphi_{4}(y)=y^{3}-y^{2}
\end{gathered}
$$


where $f_{1}(x), \ldots, f_{4}(x), \varphi_{1}(y), \ldots, \varphi_{4}(y)$ are coordinate functions for bending beams, and taking into account that the plate coordinate functions are equal to [14]

$$
\begin{gathered}
q_{1}(x, y)=f_{1}(x) V_{1}(y)+u_{1}(x) \varphi_{1}(y)-u_{1}(x) V_{1}(y), \\
q_{2}(x, y)=a f_{2}(x) V_{1}(y), \quad q_{3}(x, y)=b u_{1}(x) \varphi_{2}(y), \\
q_{4}(x, y)=f_{3}(x) V_{1}(y)-u_{2}(x) \varphi_{3}(y)+u_{2}(x) V_{2}(y), \\
q_{5}(x, y)=a f_{4}(x) V_{1}(y), \quad q_{6}(x, y)=b u_{2}(x) \varphi_{2}(y), \\
q_{7}(x, y)=f_{3}(x) V_{2}(y)+u_{2}(x) \varphi_{3}(y)-u_{2}(x) V_{2}(y), \\
q_{8}(x, y)=a f_{4}(x) V_{2}(y), \quad q_{9}(x, y)=b u_{2}(x) \varphi_{4}(y), \\
q_{10}(x, y)=u_{1}(x) \varphi_{3}(y)-f_{3}(x) V_{2}(y)+u_{2}(x) V_{2}(y), \\
q_{11}(x, y)=a f_{2}(x) V_{2}(y), \quad q_{12}(x, y)=b u_{1}(x) \varphi_{4}(y), \\
u_{1}(x)=1-x, \quad u_{2}(x)=x, \quad V_{1}(y)=1-y, \quad V_{2}(y)=y,
\end{gathered}
$$

where $u_{1}, u_{2}, V_{1}, V_{2}$ are coordinate functions of the rod during torsion, we have values of derivatives from coordinate functions

$$
\begin{aligned}
& q_{1}^{11}=\frac{6}{a^{2}}(2 x-1)(1-y), \quad q_{2}^{11}=\frac{2}{a}(3 x-2)(1-y), \quad q_{3}^{11}=0 \\
& q_{4}^{11}=\frac{6}{a^{2}}(1-2 x)(1-y), \quad q_{5}^{11}=\frac{2}{a}(3 x-1)(1-y), \quad q_{6}^{11}=0 \\
& q_{7}^{11}=\frac{6}{a^{2}}(1-2 x) y, \quad q_{8}^{11}=\frac{2}{a}(3 x-1) y, \quad q_{9}^{11}=0 \\
& q_{10}^{11}=-\frac{6}{a^{2}}(1-2 x) y, \quad q_{11}^{11}=\frac{2}{a}(3 x-2) y, \quad q_{12}^{11}=0 . \\
& q_{1}^{22}=\frac{6}{b^{2}}(2 y-1)(1-x), \quad q_{2}^{22}=0, \quad q_{3}^{22}=\frac{2}{b}(3 y-2)(1-x), \\
& q_{4}^{22}=-\frac{6}{b^{2}}(1-2 y) x, \quad q_{5}^{22}=0, \quad q_{6}^{22}=\frac{2}{b}(3 y-2) x, \\
& q_{7}^{22}=\frac{6}{b^{2}}(1-2 y) x, \quad q_{8}^{22}=0, \quad q_{9}^{22}=\frac{2}{b}(3 y-1) x \\
& q_{10}^{22}=\frac{6}{b^{2}}(1-2 y)(1-x), \quad q_{11}^{22}=0, \quad q_{12}^{22}=\frac{2}{b}(3 y-1)(1-x), \\
& q_{1}^{12}=-\frac{1}{a b}\left[\left(6 x^{2}-6 x+1\right)+\left(6 y^{2}-6 y\right)\right], \quad q_{2}^{12}=-\frac{1}{b}\left(3 x^{2}-4 x+1\right), \\
& q_{3}^{12}=-\frac{1}{a}\left(3 y^{2}-4 y+1\right), \quad q_{4}^{12}=-\frac{1}{a b}\left[\left(6 x-6 x^{2}\right)+\left(6 y-6 y^{2}-1\right)\right], \\
& q_{5}^{12}=-\frac{1}{b}\left(3 x^{2}-2 x\right), \quad q_{6}^{12}=\frac{1}{a}\left(3 y^{2}-4 y+1\right) \\
& q_{7}^{12}=\frac{1}{a b}\left[\left(6 x-6 x^{2}-1\right)+\left(6 y-6 y^{2}\right)\right], \quad q_{8}^{12}=\frac{1}{b}\left(3 x^{2}-2 x\right), \\
& q_{9}^{12}=\frac{1}{a}\left(3 y^{2}-2 y\right), \quad q_{10}^{12}=-\frac{1}{a b}\left[\left(6 x-6 x^{2}-1\right)+\left(6 y-6 y^{2}\right)\right] \\
& q_{11}^{12}=\frac{1}{b}\left(3 x^{2}-4 x+1\right), \quad q_{12}^{12}=-\frac{1}{a}\left(3 y^{2}-2 y\right) .
\end{aligned}
$$

Here, the upper indices of $q$ show the order of differentiation with respect to the corresponding coordinate, and the lower ones show the ordinal number. The functions of the distribution for transverse forces $Q_{1}$ and $Q_{2}$ can be written as

$$
C_{1}^{1}=\frac{12}{a^{3}}(1-y)-\frac{6}{a b^{2}}(2 y-1), \quad C_{1}^{2}=\frac{6}{a^{2}}(1-y), \quad C_{1}^{3}=-\frac{2}{a b}(3 y-2),
$$




$$
\begin{gathered}
C_{1}^{4}=-\frac{12}{a^{3}}(1-y)-\frac{6}{a b^{2}}(1-2 y), \quad C_{1}^{5}=\frac{6}{a^{2}}(1-y), \quad C_{1}^{6}=\frac{2}{a b}(3 y-2), \\
C_{1}^{7}=-\frac{12}{a^{3}} y+\frac{6}{a b^{2}}(1-2 y), \quad C_{1}^{8}=\frac{6}{a^{2}} y, \quad C_{1}^{9}=\frac{2}{a b}(3 y-1), \\
C_{1}^{10}=\frac{12}{a^{3}} y-\frac{6}{a b^{2}}(1-2 y), \quad C_{1}^{11}=\frac{6}{a^{2}} y, \quad C_{1}^{12}=-\frac{2}{a b}(3 y-1), \\
C_{2}^{1}=\frac{12}{b^{3}}(1-x)-\frac{6}{a^{2} b}(2 x-1), \quad C_{2}^{2}=-\frac{2}{a b}(3 x-2), \quad C_{2}^{3}=\frac{6}{b^{2}}(1-x), \\
C_{2}^{4}=\frac{12}{b^{3}} x-\frac{6}{a^{2} b}(1-2 x), \quad C_{2}^{5}=-\frac{2}{a b}(3 x-1), \quad C_{2}^{6}=\frac{6}{b^{2}} x, \\
C_{2}^{7}=-\frac{12}{b^{3}} x+\frac{6}{a^{2} b}(1-2 x), \quad C_{2}^{8}=\frac{2}{a b}(3 x-1), \quad C_{2}^{9}=\frac{6}{b^{2}} x, \\
C_{2}^{10}=-\frac{12}{b^{3}}(1-x)-\frac{6}{a^{2} b}(1-2 x), \quad C_{2}^{11}=\frac{2}{a b}(3 x-2), \quad C_{2}^{12}=\frac{6}{b^{2}}(1-x) .
\end{gathered}
$$

It is known, stress state is completely determined by internal efforts.

We consider an arbitrary $i$-th node of the plate. For this node we have three efforts: torsional and bending moments $2 M_{12 i}, M_{1 i}, M_{2 i}$.

The vector $\vec{M}$ of the nodal internal forces for the finite element takes the form

$$
\vec{M}=\left(\begin{array}{c}
\vec{M}_{1} \\
\vec{M}_{2} \\
\vec{M}_{3} \\
\vec{M}_{4}
\end{array}\right)=B \vec{V}, \quad t=2(1-\nu),
$$

where

$$
\vec{M}_{i}=\left(\begin{array}{c}
2 M_{12 i} \\
M_{1 i} \\
M_{2 i}
\end{array}\right), \quad i=1,2,3,4
$$

$B$ is a matrix of efforts; $\vec{V}$ is a vector of nodal displacements.

We note that the values of derivatives in the nodes of the finite element were used in the preparation of the matrix $B$ of efforts (3). The effort matrix $B$ is shown below

$$
B=\left(\begin{array}{ccc}
\eta_{1,1} & \ldots & \eta_{1,12} \\
\ldots & \ldots & \ldots \\
\eta_{12,1} & \ldots & \eta_{12,12}
\end{array}\right)
$$

where

$$
\begin{gathered}
\eta_{1,1}=\eta_{1,7}=\eta_{4,1}=\eta_{4,7}=\eta_{7,1}=\eta_{7,5}=\eta_{7,7}=\eta_{10,1}=\eta_{10,7}=-\frac{t}{a b} \\
\eta_{1,4}=\eta_{1,10}=\eta_{4,4}=\eta_{4,10}=\eta_{7,4}=\eta_{7,10}=\eta_{10,4}=\eta_{10,10}=\frac{t}{a b} \\
\eta_{1,2}=\eta_{4,5}=\eta_{10,2}=-\frac{t}{b}, \quad \eta_{1,11}=\eta_{4,8}=\eta_{7,8}=\eta_{10,11}=\frac{t}{b} \\
\eta_{1,3}=\eta_{4,3}=\eta_{7,12}=\eta_{10,12}=-\frac{t}{a}, \quad \eta_{1,6}=\eta_{4,6}=\eta_{7,9}=\eta_{10,9}=\frac{t}{a} \\
\eta_{2,1}=\eta_{5,4}=\eta_{8,7}=\eta_{11,10}=-6\left(\frac{1}{a^{2}}+\frac{\nu}{b^{2}}\right), \quad \eta_{3,1}=\eta_{6,4}=\eta_{9,7}=\eta_{12,10}=-6\left(\frac{1}{b^{2}}+\frac{\nu}{a^{2}}\right) \\
\eta_{2,2}=\eta_{11,11}=-\frac{4}{a}, \quad \eta_{5,5}=\eta_{8,8}=\frac{4}{a}, \quad \eta_{3,3}=\eta_{6,6}=-\frac{4}{b}, \quad \eta_{9,9}=\eta_{12,12}=\frac{4}{b}, \\
\eta_{3,2}=\eta_{12,11}=-\frac{4 \nu}{a}, \quad \eta_{6,5}=\eta_{9,8}=\frac{4 \nu}{a}, \quad \eta_{2,3}=\eta_{5,6}=-\frac{4 \nu}{b}, \quad \eta_{8,9}=\eta_{11,12}=\frac{4 \nu}{b} \\
\eta_{2,4}=\eta_{5,1}=\eta_{8,10}=\eta_{11,7}=\frac{6}{a^{2}}, \quad \eta_{3,10}=\eta_{6,7}=\eta_{9,4}=\eta_{12,1}=\frac{6}{b^{2}}
\end{gathered}
$$




$$
\begin{gathered}
\eta_{3,4}=\eta_{6,1}=\eta_{9,10}=\eta_{12,7}=\frac{6 \nu}{a^{2}}, \quad \eta_{2,10}=\eta_{5,7}=\eta_{8,4}=\eta_{11,1}=\frac{6 \nu}{b^{2}}, \\
\eta_{2,5}=\eta_{11,8}=-\frac{2}{a}, \quad \eta_{5,2}=\eta_{8,11}=\frac{2}{a}, \quad \eta_{3,12}=\eta_{6,9}=-\frac{2}{b}, \quad \eta_{9,6}=\eta_{12,3}=\frac{2}{b}, \\
\eta_{3,5}=\eta_{12,8}=-\frac{2 \nu}{a}, \quad \eta_{6,2}=\eta_{9,11}=\frac{2 \nu}{a}, \quad \eta_{2,12}=\eta_{5,9}=-\frac{2 \nu}{b}, \quad \eta_{8,6}=\eta_{11,3}=\frac{2 \nu}{b} .
\end{gathered}
$$

The remaining elements of the matrix are equal to zero. The elements of this matrix depend on the sizes $a$ and $b$ of the finite element and also depend on the parameter $t(3)$. The multiplier of this matrix is $(-D)$.

Using the expressions of transverse forces and bending moments

$$
Q_{1}=-D \vec{C}_{1}^{T} \vec{V}, \quad Q_{1}=-D \vec{C}_{2}^{T} \vec{V}, \quad \tilde{M}=-D(1+\nu) A^{T} \vec{V},
$$

we write the vector of transverse forces

$$
Q=\left(\begin{array}{c}
T_{1} \\
T_{2} \\
T_{3} \\
T_{4}
\end{array}\right)=-D C \vec{V}, \quad T_{i}=\left(\begin{array}{c}
Q_{1 i} \\
Q_{2 i} \\
\tilde{M}_{i}
\end{array}\right), \quad i=1,2,3,4
$$

Here $C$ is the matrix of transverse forces, which is determined by the values of derivatives in the nodes of the finite element; $D$ is the cylindrical rigidity of the plate; $\vec{V}$ is a vector of nodal displacements of the finite element.

$$
\tilde{M}=M_{x}+M_{y}
$$

is the generalized moment at which the value of the shear deflection $\tilde{W}(x, y)$ can be found by the following well-known formula [12]

$$
\tilde{M}(x, y)=G F \cdot \tilde{W}(x, y),
$$

where $G F$ is shear rigidity. $\vec{C}_{1}, \vec{C}_{2}, \vec{A}$ are vectors of the coordinate functions, respectively $Q_{1}, Q_{2}$ and $\tilde{M} ; i$ is the number of a current node for the finite element. The transverse forces matrix $C$ is presented below

$$
C=\left(\begin{array}{ccc}
\gamma_{1,1} & \cdots & \gamma_{1,12} \\
\cdots & \cdots & \cdots \\
\gamma_{12,1} & \cdots & \gamma_{12,12}
\end{array}\right)
$$

where

$$
\begin{gathered}
\gamma_{1,4}=\gamma_{4,4}=\gamma_{7,7}=\gamma_{10,7}=-\frac{6}{a}\left(\frac{2}{a^{2}}+\frac{1}{b^{2}}\right), \quad \gamma_{1,1}=\gamma_{4,1}=\gamma_{7,10}=\gamma_{10,10}=\frac{6}{a}\left(\frac{2}{a^{2}}+\frac{1}{b^{2}}\right) \\
\gamma_{2,10}=\gamma_{5,7}=\gamma_{8,7}=\gamma_{11,10}=-\frac{6}{b}\left(\frac{2}{b^{2}}+\frac{1}{a^{2}}\right), \quad \gamma_{2,1}=\gamma_{5,4}=\gamma_{8,4}=\gamma_{11,1}=\frac{6}{b}\left(\frac{2}{b^{2}}+\frac{1}{a^{2}}\right) \\
\gamma_{3,1}=\gamma_{6,4}=\gamma_{9,7}=\gamma_{12,10}=-6\left(\frac{1}{a^{2}}+\frac{1}{b^{2}}\right), \\
\gamma_{1,10}=\gamma_{4,10}=\gamma_{7,1}=\gamma_{10,1}=-\frac{6}{a b^{2}}, \quad \gamma_{1,7}=\gamma_{4,7}=\gamma_{7,4}=\gamma_{10,4}=\frac{6}{a b^{2}}, \\
\gamma_{2,4}=\gamma_{5,1}=\gamma_{8,1}=\gamma_{11,4}=-\frac{6}{a^{2} b}, \quad \gamma_{2,7}=\gamma_{5,10}=\gamma_{8,10}=\gamma_{11,7}=\frac{6}{a^{2} b} \\
\gamma_{1,2}=\gamma_{1,5}=\gamma_{3,4}=\gamma_{4,2}=\gamma_{4,5}=\gamma_{6,1}=\gamma_{7,1}=\gamma_{7,11}=\gamma_{9,10}=\gamma_{10,8}=\gamma_{10,11}=\gamma_{12,7}=\frac{6}{a^{2}} \\
\gamma_{1,10}=\gamma_{5,6}=\gamma_{5,9}=\gamma_{6,7}=\gamma_{8,6}=\gamma_{8,9}=\gamma_{9,4}=\gamma_{11,3}=\gamma_{11,12}=\gamma_{12,1}=\frac{6}{b^{2}} \\
\gamma_{1,3}=\gamma_{2,2}=\gamma_{4,3}=\gamma_{5,5}=\gamma_{7,12}=\gamma_{8,5}=\gamma_{10,12}=\gamma_{11,11}=-\frac{4}{a b}
\end{gathered}
$$




$$
\begin{gathered}
\gamma_{1,9}=\gamma_{2,8}=\gamma_{4,9}=\gamma_{5,2}=\gamma_{7,3}=\gamma_{8,2}=\gamma_{10,3}=\gamma_{11,8}=-\frac{2}{a b}, \\
\gamma_{1,12}=\gamma_{2,5}=\gamma_{4,12}=\gamma_{5,11}=\gamma_{7,6}=\gamma_{8,11}=\gamma_{10,6}=\gamma_{11,5}=\frac{2}{a b}, \\
\gamma_{6,5}=\gamma_{9,8}=\frac{4}{a}, \quad \gamma_{9,9}=\gamma_{12,12}=\frac{4}{b}, \\
\gamma_{3,5}=\gamma_{12,8}=-\frac{2}{a}, \quad \gamma_{6,2}=\gamma_{9,11}=\frac{2}{a}, \quad \gamma_{3,12}=\gamma_{6,9}=-\frac{2}{b}, \quad \gamma_{9,6}=\gamma_{12,3}=\frac{2}{b} .
\end{gathered}
$$

The remaining elements of the transverse forces matrix are equal to zero.

Replacement of the original construction with a set of discrete elements allows unifying the calculation of various building objects: rod systems, thin-walled and massive structures and real structures that combine rods, plates, shells etc. This circumstance makes the finite element method very universal and explains its increased popularity.

Today, the finite element method is a powerful tool for engineering analysis and physical research through the creation of software packages such as ANSYS, MSC.NASTRAN, MSC.MARC, COSMOS, ABAQUS. These packages of computer programs implement the computational process of the finite element method, and also have a convenient interface for input of initial data, control of the calculation process and processing of calculation results [15].

\section{References}

1 Завьялов В.Н. Основы строительной механики пластин / В.Н. Завьялов, Е.А. Мартынов, В.М. Романовский. - Омск: СибАДИ, 2012. - 116 с.

2 Косауров А.П. Анализ и особенности методов при расчете пластин и оболочек на изгиб / А.П. Косауров, П.В. Тимофеев. - М.: Фонд «Основание», 2013. - 17 с.

3 Awrejcewicz J. Theory of plates and shells: new trends and applications / J. Awrejcewicz, I.V. Andrianov // International Journal of Nonlinear Sciences and Numerical Simulation. - 2014. - 5(1). - P. 23-36. DOI: $10.13140 / 2.1 .2244 .5767$

4 Delale F. Stress analysis of multilayered plates around circular holes / F. Delale // International Journal of Engineering Science. - 1984. - 22(1). - P. 57-75. DOI: 10.1016/0020-7225(84)90132-0

5 Voyiadjis G.Z. Elasto-Plastic and Damage Analysis of Plates and Shells / G.Z. Voyiadjis, P. Woelke. Springer-Verlag Berlin Heidelberg, 2008. - 208 p. DOI: 10.1007/978-3-540-79351-9-9

6 Librescu L. A few remarks concerning several refined theories of anisotropic laminated plates / L. Librescu, J.N. Reddy // International Journal of Engineering Science. - 1989. - 27(5). — P. 515-527. DOI: 10.1016/0020-7225(89)90004-9

7 Andrianov I.V. Asymptotic Methods in the Theory of Plates with Mixed Boundary Conditions / I.V. Andrianov, J. Awrejcewicz, V.V. Danishevs'kyy, A.O. Ivankov. - Wiley, 2014. - 288 p. DOI: 10.1002/9781118 725184

8 Akhanova A.S. On the calculation of plates by the series representation of the deflection function / A.S. Akhanova, G.A. Yessenbayeva, N.K. Tursyngaliyev // Bulletin of the Karaganda University. Mathematics series. - 2016. - № 2(82). - P. 15-22.

9 Yessenbayeva, G.A. On the calculation of rectangular plates by the variation method / G.A. Yessenbayeva, A.A. Smailova // Bulletin of the Karaganda University. Mathematics series. - 2016. - № 2(82). - P. 5662.

10 Животов А.Г. О расчете прямоугольных пластин методом тригонометрических рядов / А.Г. Животов, Г.А. Есенбаева // Вестн. Караганд. ун-та. Сер. Математика. - 2015. - № 3(79). - С. 44-49.

11 Bass J. Adaptive finite element methods for a class of evolution problems in viscoplasticity / J. Bass, J.T. Oden // International Journal of Engineering Science. - 1987. - 25(6) - P. 623-653. DOI: 10.1016 /0020-7225(87)90053-X

12 Тимошенко С.П. Теория упругости / С.П. Тимошенко, Дж. Гудьер. - М.: Наука, 1979. — 560 с.

13 Турсунов K.А. Прямоугольный конечный элемент пластины / К.А. Турсунов, А.Е. Елешова // Тр. ун-та. Раз. 5: Математика. Механика. - 2000. - Вып. 1. - С. 61-63. 
14 Yessenbayeva G.A. On the calculation of the rectangular finite element of the plate / G.A. Yessenbayeva, D.N. Yesbayeva, T.Kh. Makazhanova // Bulletin of the Karaganda University. Mathematics series. 2018. - No. 2(90). - P. 150-156.

15 Фокин В.Г. Метод конечных элементов в механике деформируемого твердого тела / В.Г. Фокин. Самара: Самар. гос. техн. ун-т, 2010. - 131 с.

\title{
Г.А. Есенбаева, Д.Н. Есбаева, Н.К. Сыздыкова \\ Тікбұрышты пластиналарды есептеу үшін соңғы элементтердің әдісі туралы
}

\begin{abstract}
Мақала тікбұрышты пластиналардың иілу мәселелерін зерттеуге арналған. Пластиналардың үлкен қолданбалы маңызы бар және ғылым мен техниканың әртүрлі салаларында әр жерде кездеседі. Пластиналардың иілуін есептеу соңғы элементтер әдісімен орындалды. Авторлар пластинаның тікбұрышты соңғы элементінің деформацияланған және кернеулі күйін есептеу әдісінің құрылымын берген, оның негізгі компоненттерін анықтаған, тікбұрышты пластиналарды есептеудің классикалық тәсілін сипаттаған. Математикалық есептеу аппараты пластиналарды есептеу үшін қажетті көлемде ұсынылған. Мақала механиктерге, физиктерге, инженерлерге және техникалық мамандықтардың мамандарына бағытталған.
\end{abstract}

Kiлm сөздер: соңғы элементтер әдісі, тікбұрышты пластинаның иілуі, пластинаның соңғы элементі, пластинаның иілу функциясы, координаттық функциялар.

\section{Г.А. Есенбаева, Д.Н. Есбаева, Н.К. Сыздыкова \\ О методе конечных элементов при расчете прямоугольных пластин}

\begin{abstract}
Статья посвящена исследованию задач изгиба прямоугольных пластин, которые имеют большое прикладное значение и встречаются повсеместно в самых различных отраслях науки и техники. Расчет изгиба пластин выполнен методом конечных элементов. Авторами представлена структура метода расчета деформированного и напряженного состояния прямоугольного конечного элемента пластины, выделены его основные компоненты, охарактеризован классический подход расчёта прямоугольных пластин. Математический аппарат расчета предложен в необходимом для расчёта пластин объеме. Статья ориентирована на механиков, физиков, инженеров и специалистов технических специальностей.
\end{abstract}

Ключевые слова: метод конечных элементов, изгиб прямоугольной пластины, конечный элемент пластины, функция прогиба пластины, координатные функции.

\section{References}

1 Zavyalov, V.N., Martynov, E.A. \& Romanovsky, V.M. (2012). Osnovy stroitelnoi mekhaniki plastin [Basics of structural mechanics of plates]. Omsk: SibADI [in Russian].

2 Kosaurov, A.P. \& Timofeev, P.V. (2013). Analiz $i$ osobennosti metodov pri raschete plastin $i$ obolochek na izhib [Analysis and features of methods for calculation of plates and shells for bending]. Moscow: Fond «Osnovanie» [in Russian].

3 Awrejcewicz, J. \& Andrianov, I.V. (2014). Theory of plates and shells: new trends and applications. International Journal of Nonlinear Sciences and Numerical Simulation, 5(1), 23-36.

DOI: $10.13140 / 2.1 .2244 .5767$ 
4 Delale, F. (1984). Stress analysis of multilayered plates around circular holes. International Journal of Engineering Science, 22(1), 57-75. DOI: 10.1016/0020-7225(84)90132-0

5 Voyiadjis, G.Z. \& Woelke, P. (2008). Elasto-Plastic and Damage Analysis of Plates and Shells. SpringerVerlag Berlin Heidelberg. DOI:10.1007/978-3-540-79351-9-9

6 Librescu, L. \& Reddy, J.N. (1989). A few remarks concerning several refined theories of anisotropic laminated plates. International Journal of Engineering Science, 27(5), 515-527. DOI: 10.1016/00207225(89)90004-9

7 Andrianov, I.V., Awrejcewicz, J., Danishevs'kyy, V.V. \& Ivankov, A.O. (2014). Asymptotic Methods in the Theory of Plates with Mixed Boundary Conditions. Wiley. DOI: 10.1002/9781118725184

8 Akhanova, A.S., Yessenbayeva, G.A. \& Tursyngaliyev, N.K. (2016). On the calculation of plates by the series representation of the deflection function. Bulletin of the Karaganda University. Mathematics Series, 2(82), 15-22.

9 Yessenbayeva, G.A. \& Smailova, A.A. (2016). On the calculation of rectangular plates by the variation method. Bulletin of the Karaganda University. Mathematics Series, 2(82), 56-62.

10 Zhivotov, A.G. \& Yessenbayeva, G.A. (2015). O raschete priamouholnykh plastin metodom trihonometricheskikh riadov [On the calculation of rectangular plates by the method of trigonometric series]. Bulletin of the Karaganda University. Mathematics Series, 3(79), 44-49 [in Russian].

11 Bass, J. \& Oden, J.T. (1987). Adaptive finite element methods for a class of evolution problems in viscoplasticity. International Journal of Engineering Science, 25(6), 623-653. DOI: 10.1016/0020-7225(87) 90053-X

12 Timoshenko, S.P. \& Goodier, J. (1979). Teoriia upruhosti [Theory of elasticity]. Moscow: Nauka [in Russian].

13 Tursunov, K.A. \& Eleshova, A.E. (2000). Priamouholnyi konechnyi element plastiny [The rectangular finite plate element]. Proceedings of the University. Section 5: Mathematics. Mechanics, 1, 61-63 [in Russian].

14 Yessenbayeva, G.A., Yesbayeva, D.N. \& Makazhanova, T.Kh. (2018). On the calculation of the rectangular finite element of the plate. Bulletin of the Karaganda University. Mathematics Series, 2(90), 150-156.

15 Fokin, V.G. (2010). Metod konechnykh elementov v mekhanike deformiruemoho tviordoho tela [The finite element method in solid mechanics]. Samara: Samarskii hosudarstvennyi tekhnicheskii universitet [in Russian]. 